\title{
The quantitative analysis between application patents and the market about Japanese digital camera manufacturers
}

\author{
Jun HOSOYA *, Yoji TANIGUCHI ${ }^{\dagger}$
}

\begin{abstract}
The Japanese Ministry of Public Management, Home Affairs, Posts and Telecommunications makes the digital camera the product with the strong international competitiveness. More than 90 percent of the world shipment quantity of a digital camera are Japanese manufacturer. In this paper, 7 Japanese digital camera manufacturers were divided into the existence camera manufacturer type which deals with a camera from the old analog film age, the new entry electronics manufacturer type which makes the digital appliance the strong point field. Whether the outcomes of research and development were making a market however reflected quantitative determination analyzed. The contents of quantitative analysis divided patent application data of each company which was an outcome of research and development into analog technology and digital technology. The analysis was considering the time lag each technology was making reflected to shipment quantity. The analysis was considering 63 kinds of time lag in each analysis period covered. The analysis was considering time series variation for 7 years. 3 companies out of 7 companies, the result of analysis was the following 2. "The patents of the technical field to which a catch up was necessary" needed time in the relation to the shipment quantity more than "the patents of a good technical field". "To shipment quantity per 1 patent of the technical field to which a catch up was necessary, it became more influential than the patents of a good technical field".
\end{abstract}

Keywords: Digital camera, quantitative analysis, regression analysis, time lag, patent data

\section{Introduction}

Japanese MIC (Ministry of Internal Affairs and Communications) started the publication of "the ICT international competitiveness index" from 2008. "ICT international competitiveness index" is a measurement index for reinforcement of the international competitiveness of the ICT industry. The name of the index was changed to "IoT international competitiveness index" in 2017 and the publication is continued. The index (2013 version) raise 20 items (as main terminal, equipment, device seven areas).

MIC calculates these item market shares. The market share is Japanese export value occupied in ex-port value of the whole world. MIC analyzes the market share and assumes an index of the

* Waseda University, Tokyo, Japan

$\dagger$ Daiichi Institute of Technology, Tokyo, Japan 
competitiveness. MIC describes "strong Japanese export competitiveness items are 2 kinds" in the index. MIC describes that the strongest list of articles is a digital camera. A digital camera is a camera recording pictorial image digitally. The world shipment quantity of the digital camera of 2017 is approximately 22 million. The Japanese company of three high ranks occupies approximately $90 \%$ of the shipment quantity (July 12, 2018 / Nikkei industry newspaper in Japan). The digital camera shipment amount of money grows up than 9 times for 10 years from 1999. The shipping amount of digital camera in 1999 was 227,900 million yen according to publication of CIPA (Camera \& Imaging Products Association in Japan). The shipping amount of digital camera in 2008 was 2,164 billion yen. Thus a digital camera market is big and is in the oligopoly state. What kind of Japanese company deals with the digital camera? It shows the situation from 2001 through 2016 to figure 1 in element in the figures (the source: the Nihon Keizai Shimbun, Japanese economy industry newspaper, companies announcement) of the host company of the announced digital camera world delivery quantity every year.

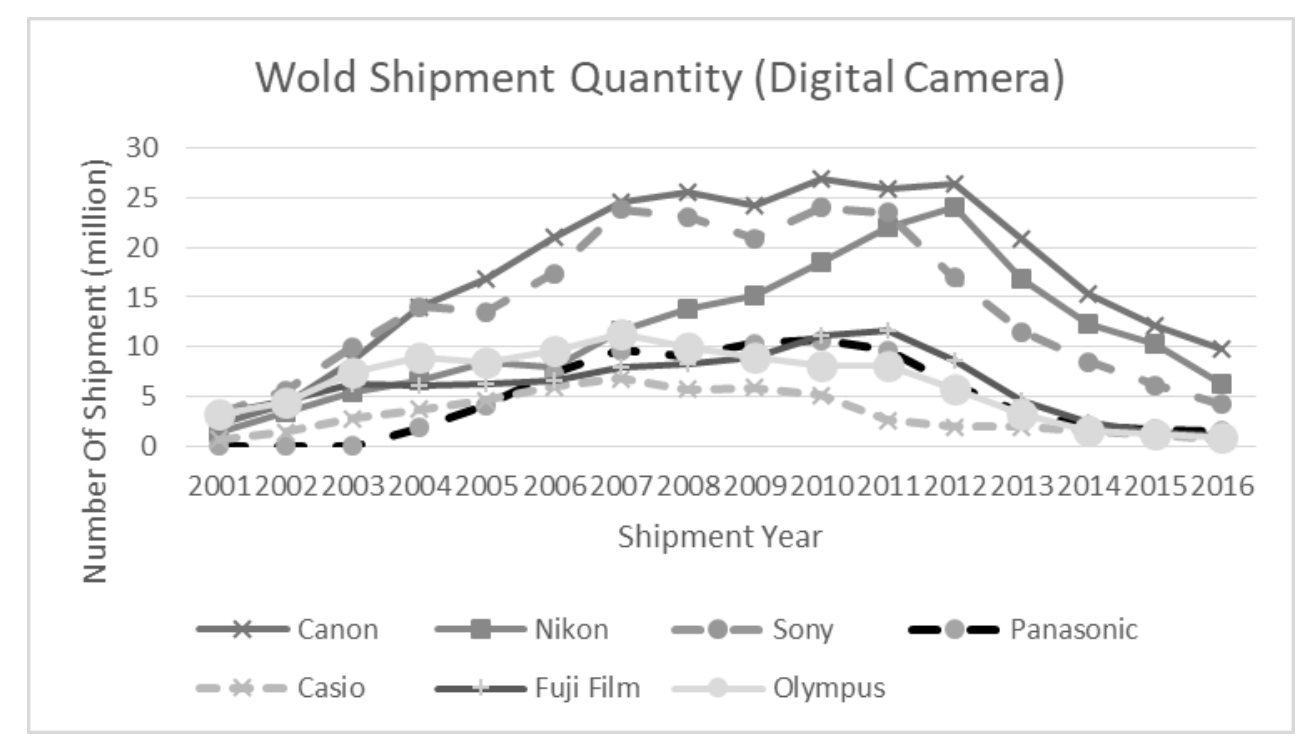

Figure 1: World Shipment Quantity (Digital Camera)

The source: the Nihon Keizai Shimbun, Japanese economy industry newspaper, companies announcement

The dominance enterprises are "existing camera maker cluster dealing with a camera from the old silversalt film era" and "the new comer electronics maker configuration group which is good at a digital appliance". This is because digital cameras are two technological fusion products. The 1st is the technology which continues from an old film camera. The 2nd is digital technology with development of IT. It is thought that an existing camera maker is good at the techniques such as a lens mechanism or the shutter which continue from old film camera. On the other hand, it is thought that a new comer electronics maker is good at the techniques such as image processing or the pictorial image element becoming the digital technology with the progress of the IT. In other words Japanese companies dealing with a digital camera have a technical field to be proud each. But there are also technology which aren't being possessed in a Japanese camera enterprise. An existence camera manufacturer cluster needs learning of digital technology with development of IT. A new entry electronics manufacturer cluster needs learning of technology of old film camera. In this analysis, in the digital camera industry, which is an integrated 
technology product, we would like to clarify to what extent the research and development of product manufacturers with different specialty technology fields are reflected in the market. For example, how much is the research and development results of each technology that is integrated contributing to product sales? Also, how long does it take for the R \& D results of each technology to be integrated to contribute to product sales? For this purpose, in this analysis, an analysis method in which time series analysis is added to time lag analysis is used. Data for analyses is "the world shipment quantity of the digital camera" and "patent data related to camera".

\section{Preceding Studies}

The effectiveness of R\&D and the quality of its results has been digitalized based on the contents published in theses and the quantity of quotations by other theses, etc. and have been opened to the public. "The National Indicator Reports" published by the National Scientific Board in the U.S is the most representative one of them. Other than that, the National Science Foundation in the U.S and the Science Policy Research Unit in the U.K. edit and publish data books that are of the same kind, but digitalized in a different way. These data have been quoted and utilized as an indicator representing the quality and progress of the country's technology for academic theses and policy-making. These data enable us to assess the research results of not only nations but also public research organization and major universities. On the other hand, in qualitative and quantitative studies on the result analysis of $R \& D$ in companies, it is generally accepted to approach it by analyzing patent and patent applications data [1]. This is predicated on the idea that it is greatly useful because patent data covers all technical fields by time-sequentially. Therefore, especially in large companies, patent date is used as one of the predominant indexes for research and development results [2].

As for R\&D activities and patent data in firms, it has been reported that in almost all industries in Japan, the more research and development budget there is, the more the quantity of patent applications increases. In addition, credibility of evaluation of $R \& D$ activities using patent date and its results has been established [3]. Also, Kendall (2010) discovered correlations between $R \& D$ investment costs and the quantity of patents and between the quantity of patents and new products after analyzing $R \& D$ investment costs, the quantity of patents and new products from over 19-year samples from 35 industries and 272 companies [4]. Lev and Sougiannis (1996) suggests that $R \& D$ investments are correlated with evaluation from the stock market a few years later [5]. Pakes (1986) also introduced option theory by using parameters such as a renewal fee that has to be paid to keep the patent in force and the rate of obsolescence of technology value [6]. This enables patent holders to recognize that patent registration is valuable at a certain level. Delving into more details, some studies have been carried out to study the subject of patent data in the broad sense, including public, published and patent data, to determine each company's direction and innovativeness of R\&D. Kodama (1986) visualized technical trends in patent application among companies by using the Input Output Table, identified the relationship between the contents of patent applied and R\&D expenses, and reported how leading companies in Japan diversify R\&D [7]. Moreover, several studies also have been made on the relationship between the quantity of patent, technology classification, and companies' technology strategies, more specifically. Tsuji (2002) and Suzuki (2004) analyze Canon's patent application from the perspective of technology classification and year of application and describe Canon is working on establishing a system of R\&D team and advancing business strategy [8] [9]. In addition, 
making a comparison of the quantity of patent applications in each county over fifteen years between two global heavy electronic corporations: General Electric (GE) and ABB Ltd., Bergek and Berggren (2004) pointes out differences in international R\&D strategies between GE and ABB. Unexpectedly, the result shows ABB takes a more proactive approach to international intellectual property strategy and obtains results in each region evenly [10]. Thus, analysis on the quantity of patent applications by companies is an important indicator not only of quality and effectiveness of $R \& D$ from the perspective of its correlation with $R \& D$ expenses, but also it is used to predict the future possibilities of $R \& D$ strategies as the outcome of $R \& D$ expenses, as well. Moreover, there are some unique studies, which aim at determining not the effectiveness or direction of a specific company's $\mathrm{R} \& \mathrm{D}$, but the trend of a specific technical field, and progress or direction of R\&D by companies in the field. In Pilkington and Dyerson's study (2006), they examined patent applications regarding the electronic automobile field and investigate content and the quantity of patent applications by key R\&D players (companies) in the field [11]. As a result, they conclude that the speed of R\&D in the electronic automobile field was affected and accelerated by exhaust regulations for environmental countermeasures. In this way, analyses using patent data have contributed to understanding various events regarding $R \& D$, for instance, enables to clarify the effectiveness of companies' $R \& D$ and the field they concentrate on, and demonstrate the content of their technological strategy by comparing with competitors.

The following past studies have stated that corporate research activities affect product superiority and, as a result, generate profits. The patents measures reflecting the volume of companies' research activity were reliably associated with the future performance of R\&D-intensive companies in capital markets [12]. Cooper (1987) concluded that product superiority is the quantity one factor influencing commercial success and that project definition and early, predevelopment activities are the most critical steps in the new products development process [13]. Henard (2004) stated that there is a strong correlation between new product advantage and new product performance [14]. Song (1997) stated that it can achieve high performance in the market, such as sales and profits, when differentiated from competing products [15]. Improving the performance of a new product was an important result of the superiority of the new product [16]. There are other papers that patents are useful for improving productivity and marketing. The company's future performance has a positive relationship with patent quality, which was predicted to be more powerful for productive and innovative companies [17]. In other studies, artificial neural networks were used to investigate the impact of quantitative and qualitative patent indicators on corporate market value in the US pharmaceutical industry. Furthermore, it was stated that in order to increase market value, it is necessary to invest more resources in research and development activities and to enhance the advantages in the most important technical fields [18]. There is also a paper that analyzes the relationship between "citation information described in patents" and "quantity of product developments" [19]. It is noted in several papers that patent management is important for marketing. It is also discussed that intellectual property management activities are adopted in a practical framework for marketing and strategy [20]. The role of marketing in patent management is explained, including technology, positioning and licensing [21]. In addition to these viewpoints, there are also papers that add the viewpoints of existing companies and new entrants as follows. Lieberman surveyed the theoretical and empirical literature on mechanisms that confer advantages and disadvantages on first-mover firms [22].

It is analyzed in past papers that it is important for companies to diversify like the new entrants of digital camera manufacturers described in this paper [23] [24]. In addition, it has been analyzed that it is important to make effective use of the company's existing resources even when entering 
a new market [25]. Existing companies can develop existing technologies most quickly, and are skilled at developing new products by combining new technologies and existing technologies through the acquisition and accumulation of new technologies and resources [26]. Meanwhile, Schnars analyzed the quantification and qualitative analysis of how new entrants retain a dominant position in the market [27].

\section{Methodology}

Japanese digital camera enterprises are divided into an existence camera manufacturer crowd and a new entry electronics manufacturer crowd by this analysis. In each Japanese digital camera enterprises, Quantitative determination analyzes an outcome of research and development and the relation of the market. The target enterprises are digital camera world shipment quantity high rank company. The name of the target enterprise are Canon, Nikon, Fuji Film, Olympus, Sony, Panasonic and Casio. Canon, Nikon, Fuji Film and Olympus are an existence camera manufacturer from the film age. Sony, Panasonic and Casio are new entry electronics manufacturer. Data for analyses are "the world shipment quantity of a digital camera" and "camera related patent data". IPC (International patent code) is used to specify the kind of technology of patents. IPC is the worldwide technological classification code. The Patent Office gives IPC to patent data. A specialized examination official of the technical field of the Patent Office concerned gives IPC to these for application data. Thus, it is thought that the reliability of the given sequence is high. More than one of IPC are usually given to each patent data. IPC which symbolizes technology of the invention data applied for is called "Main IPC". "Main IPC" is given certainly to all bibliographies. More than one technology are sometimes included in one of invention. The Patent Office gives more than one IPC to the invention in that case. All except for Main IPC is called CO - IPC in more than one IPC. This IPC is used to specify a digital camera related patent by this analysis. "The patent which makes the analog part from the film age the main feature" is called "analog patent" by this analysis. "The patent which makes the technology added newly from a digital camera the main feature" is called "digital patent". IPC is used for difference between this "analog patent" and "digital patent". Since putting it in the analysis target, a fusion patent of "analog patent" and "digital patent" is also considered. It's judged by Main IPC in which field it's a characteristic patent. When Main IPC is "technological classification of the lens and optical subsystem: G02B1 - G02B17" or "technological classification of a camera: G03B1 - G03B19" the invention is called "analog patent". When Main IPC is "technological classification related to digital processing: H04N5/22 - 25" or "technological classification of image pickup device: H04N5/33 - 36, H01L27/146 - 148", the invention is called "digital patent". These technological classifying processes were put into effect by making reference to a document (Japan Patent Office technical report). Data for analyses uses applied patents for Japan Patent Office. There are applying date of patent data from 1995 to 2016. A patent search working date is the last day of July, 2018. An analytical method in this analysis is using a regression analysis. Response variable of a regression analysis is the world total shipment of a digital camera. Predictor variable of a regression analysis is the quantity of digital camera related patent applications. The quantity of observations used for a regression analysis is set to 10 years. A starting year of a data set is set to 7 from 2001 to 2007. For example when a starting year of a data set is set from 2001, it'll be a data set until 2010. When a starting year of a data set is set from 2007, it'll be a data set until 2016. So, a measurement period of objective variable was set to 2016 from 2001. In this way, it can analyze the time series variation for seven years. From here, it's explained about the explanatory variable (digital camera-related patent application 
amount). The quantity of observations of the predictor variable is made "for 10 years which continue" like objective variable. In this analysis, the digital camera-related patent divides into an analog patent and a digital patent. This is because it's different in good technology depending on the enterprises which deal with a digital camera. The difference in the good technology in the digital camera field seems to have an influence on the shipment quantity. A time lag analysis is performed by this analysis. The time lag is a thing from "the year when each enterprise applies for an outcome of research and development as a patent" to "the year to which the product which reflected an outcome of research and development is shipped". It is a common technique to analyze R \& D results and time lag until commercialization [28] [29]. The time lag is set to 0 to 7 years as a finite difference of a patent application year and a shipment year. The time lag is set as each of Analog patent and Digital patent.

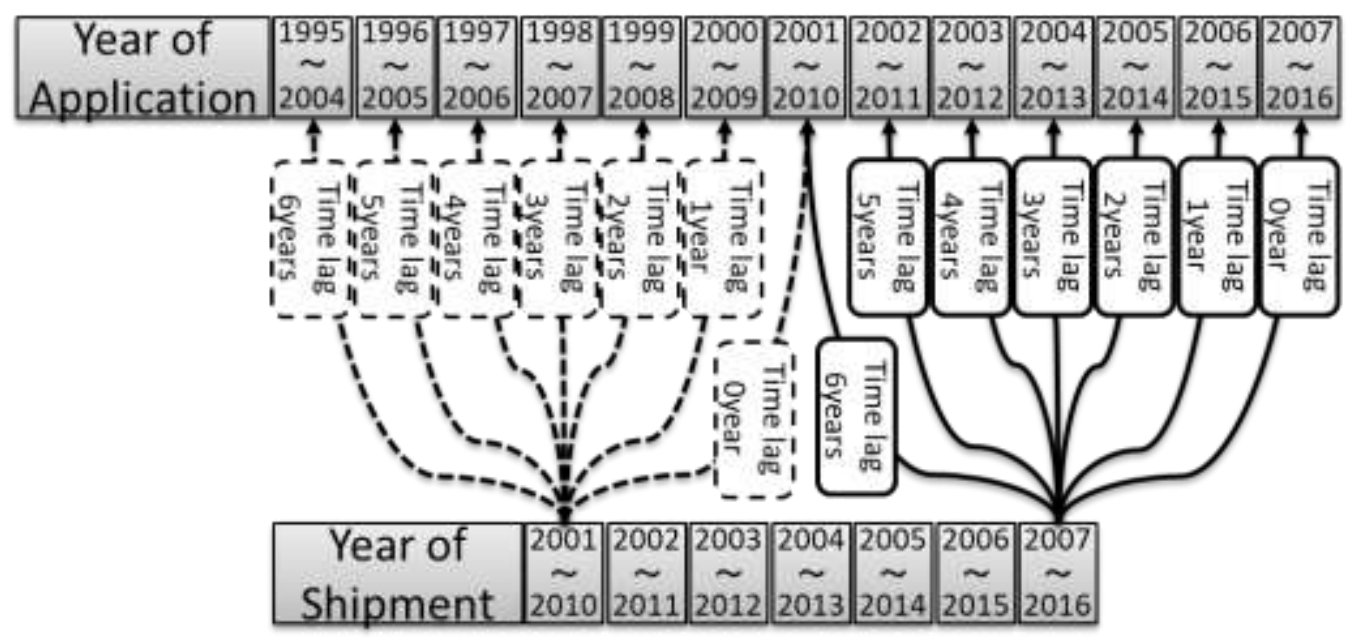

Figure 2: Time lag between "Year of Application" and "Year of Shipment"

For example, a data set of the shipment quantity thinks about case of "2001 through 2010" (explanation with the dashed line of figure 2). In the case of "a time lag 0 year", the period of patent data is "2001 through 2010". In the case of "a time lag 1 year", the period of patent data is "2000 through 2009". In the case of "a time lag 6 years", the period of patent data is "1995 through 2004". A measurement period of predictor variable will be 22 years (1995 to 2016) added for 6 years in a measurement period of objective variable.

In this article, it considers about the problem of the variable selection of the multiple regression analysis. It chooses the most suitable model in "the case which used a part of the explanatory variable" when "it uses all explanatory variable". The explanatory variable to use in the multiple regression analysis by this analysis is two. Therefore predictor variable compares one in case of 1 and 2. It performs a simple linear regression analysis using one explanatory variable beforehand. Single regression analysis (the quantity of analog patents and shipment quantity) is put into effect. And, single regression analysis (the quantity of digital patents and shipment quantity) is put into effect. In a selection criterion to mention later from these plural existing models, it carries out the most suitable model selection. Even this single regression analysis will establish and analyze a time lag. In other words the quantity of the pattern of the time lag in case of the multiple 
regression analysis becomes 49 pattern. This is because it becomes the full matrix in consideration of the rag of for each seven years of an analog patent and the digital patent. The quantity of the pattern in case of the simple linear regression analysis "an analog patent and a digital patent, each it is with 14 pattern which considered the lag of seven years". The quantity of the pattern of the time lag in this way becomes 63 (multiple regression analysis 49 pattern, simple linear regression analysis 14 pattern). It performs seven sets of time series analyses as things mentioned above for each target company. 63 patterns (multiple regression analysis 49 pattern, simple linear regression analysis 14 pattern) of time lag exists in each set. It shows the conceptual diagram of the time lag of the regression analysis in this analysis in figure 3 .

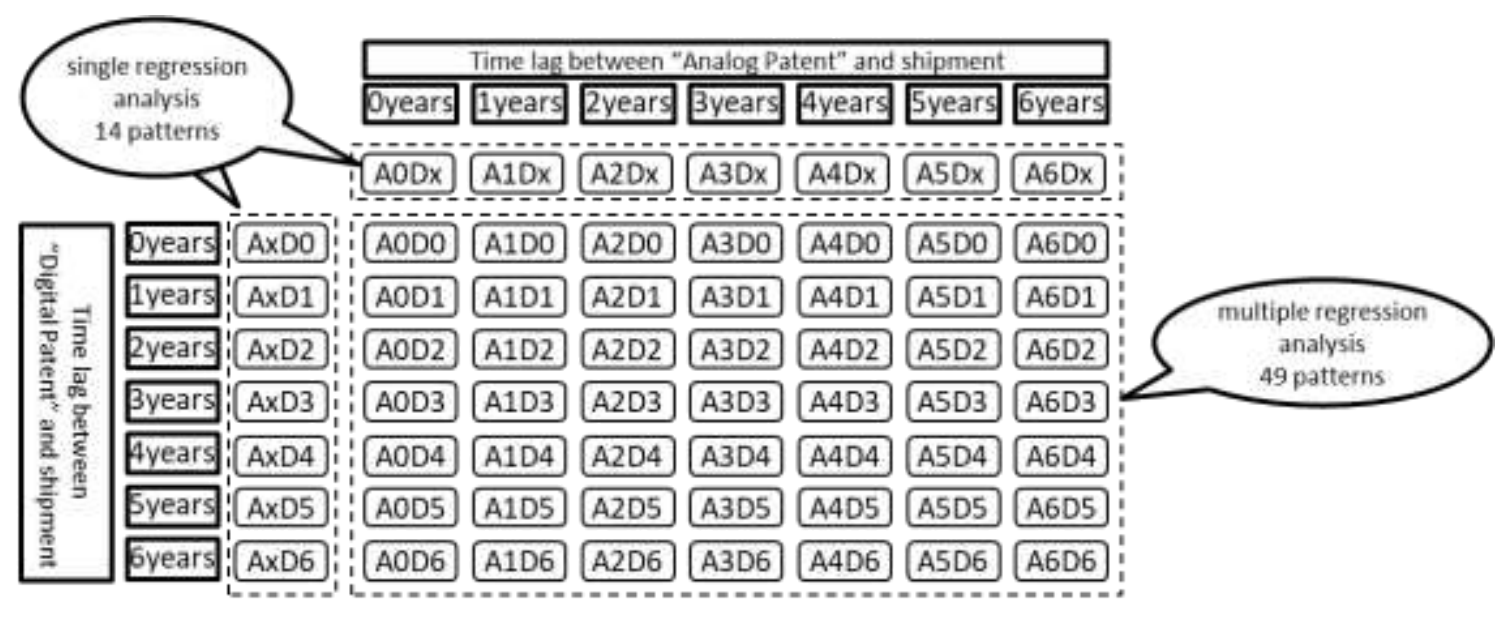

Figure 3: The regression analysis which considered time lag

\begin{abstract}
"AmDn" in a figure shows the quantity of years of the time lag. There is A in the meaning of the analog patent, and quantity $\mathrm{m}$ included just after that shows the analog patent application year and difference (time lag) of the shipment quantity of years. Similarly, there is D in the meaning of the digital patent, and quantity $n$ included just after that shows the digital patent application year and difference (time lag) of the shipment quantity of years. In other words, with "A1D3," the time lag of the analog patent is 1 year and e time lag of the digital patent is 3 years. Thus, the time lag of the analog patent gets longer so as to go to right side part of figure 3 , and the time lag of the digital patent gets longer so as to go to bottom part. In addition, in the case of the simple linear regression analysis that assumed only an analog patent or a digital patent explanatory variable, it lists alphabet " $x$ " in a part of the quantity of years in the time lag of the patent not to use. In other words, with "AxD3," it shows that the digital patent time lag without the analog patent says the simple linear regression analysis of three years.

The standard from which the best pattern is chosen is written in below. As "selection criterion 1", coefficient of determination chooses things more than 0.7. In each regression analysis, to keep an adequacy of the calculated regression formula; an index indicating observed value of the objective variable and the explanation force of the predictor. As "selection criterion 2", it chooses things less than 0.1 with meaningful probability. To judge explanatory variable to have objective variable and a relationship. As "selection criterion 3", VIF (Variance Inflation Factor) chooses things less than 2.0. An index to detect multicollinearity between the independent variable to remove multicollinearity. Only in the case of multiple regression analysis, this carries out. As "selection criterion 4", it chooses the thing that the sign of the simple correlation coefficient
\end{abstract}


accords with coefficient of multiple correlation. To remove multicollinearity like selection criterion 3. Only in the case of multiple regression analysis, it carries out this reference. As "selection criterion 5", it chooses the lowest case of the value of the Akaike's Information Criterion AIC (Akaike's Information Criterion) [30].

Table 1: Selection standard

\begin{tabular}{ll}
\hline $\begin{array}{c}\text { Selection } \\
\text { standard }\end{array}$ & \multicolumn{1}{c}{ The Contents of Standard } \\
\hline 1 & Coefficient of determination chooses things more than 0.7. \\
2 & Less than 0.1 with meaningful probability \\
3 & VIF (Variance Inflation Factor) chooses things less than 2.0. \\
4 & The sign of the simple correlation coefficient accords with coefficient of multiple correlation. \\
5 & $\begin{array}{l}\text { The lowest case of the value of the Akaike's Information Criterion AIC } \\
\text { (Akaike's Information Criterion) }\end{array}$ \\
\hline
\end{tabular}

\section{The outline of analysis data}

\subsection{World shipment quantity of Digital camera}

By this analysis, it uses the world shipment quantity of the digital camera for 17 years from 2001 through 2016 (figure 1). All seven Japanese companies increase the shipment quantity from 2001 and peak from 2007 through 2012. Shipment quantity of each enterprise becomes on the decline to 2016. When it's compared with the most age, shipment quantity of Casio, Fuji Film and Olympus of 2016 will be less than $10 \%$. The maker which has become the top of the shipment quantity of each age is only two companies of Sony and Canon.

\subsection{The quantity of the digital camera-related patent application}

By this analysis, it uses the quantity of the digital camera-related patent application from 1995 through 2016. The analog patent comes to have more quantity of the applications of the filmmaker than the quantity of the applications of the electronics maker except 2009. Many manufacturers tend to decrease the quantity of applications to 2016. But Canon tends to increase the quantity of applications to 2016. As of 2016, the quantity of the applications of Canon of the quantity of the analog patent application first place becomes more than 4 times than Fuji Film of the same year second place. The maker which has become the top of the quantity of the analog patent application of each age is only Canon, Nikon, and Fuji Film. 


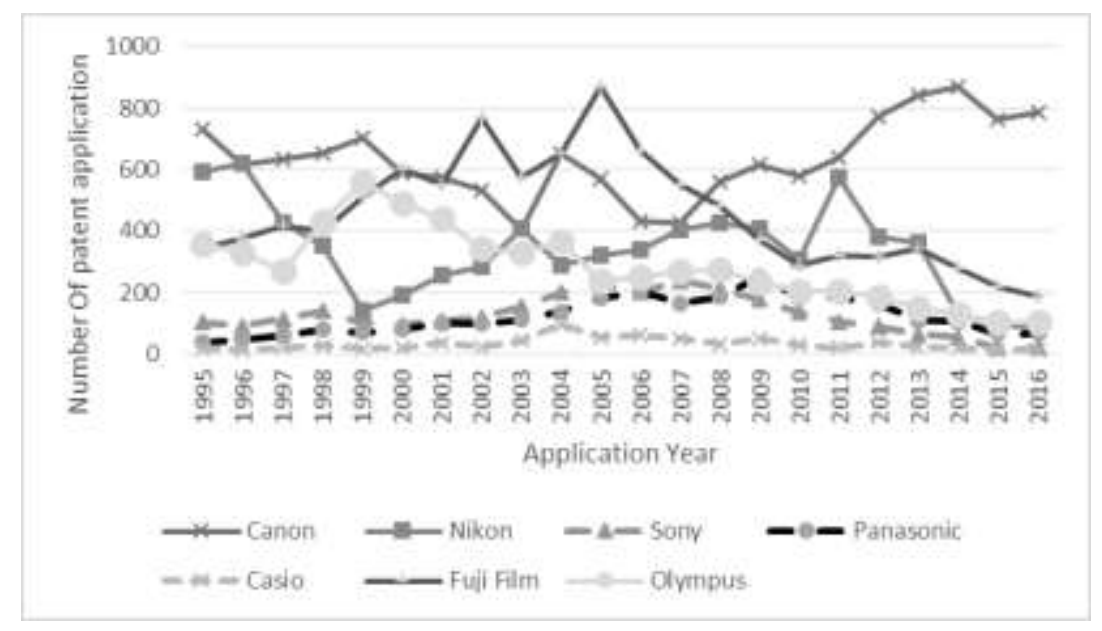

Figure 4: The quantity of patent application (Analog)

The quantity of the digital patent application peaks from 2004 through 2009 except Canon. Many manufacturers tend to decrease the quantity of applications to 2016 like an analog patent. But Canon tends to increase the quantity of applications. As of 2016, the quantity of the applications of Canon of the quantity of the digital patent application first place becomes more than 7 times than Sony of the same year second place. The maker which has become the top of the quantity of the digital patent application of each age is only Canon, Sony and Fuji Film.

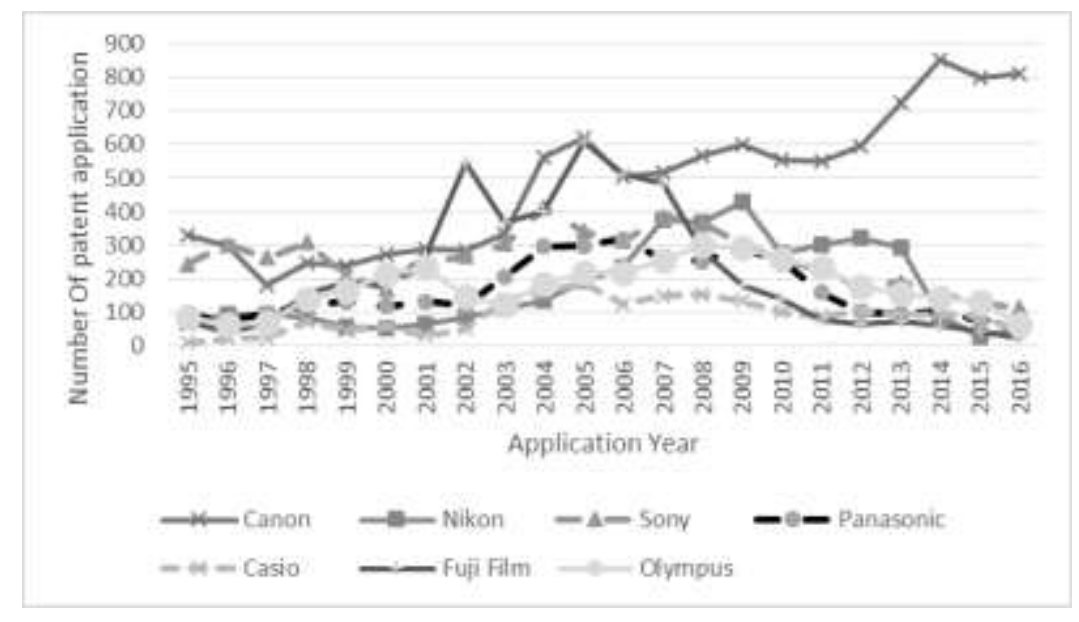

Figure 5: The quantity of patent application (Digital)

\section{The result of analysis}

By the analysis procedures of three chapters, it carried out the following analyses about seven Japanese companies which was a digital camera maker. A regression analysis of 7 periods of time series variation was put into effect. 63 kinds of time lag was considered in each period. There were 3087 regression models in this analysis. A model was elected by above-mentioned selection reference in each period. In all seven companies, the model which did not clear a 
selection criterion do not exist. But the model that was lower value of the AIC "a simple linear regression analysis having one variable" than "two multiple regression analysis explanatory variable" appeared in the data set to exist. Because selection reference is cleared, the decision coefficient of the model is at least more than 0.7. Therefore the precision of the model is good. The results of analysis of each enterprise are explained after the next clause.

\subsection{Canon}

The average of AIC of Canon is lowest during 7 companies of this analysis. In other words, applying of a regression analysis result of Canon is bad compared with other 6 companies. Shipment quantity of Canon indicates a downward trend to 2016 described at 4 chapter. On the other hand, digital camera related invention of Canon is the increased tendency to 2016. Therefore applying seems to become bad for a regression analysis result of Canon. There are no tendencies about the time lag between the application of patents (analog and digital) and the total shipment. For the analog regression coefficient, 5 periods are minus in 6 periods except "NA period". And, 6 periods of average is also minus. Such tendency isn't seen by other 6 companies. The digital regression coefficient tends to fall. The digital regression coefficient is minus in 2 periods of second half. The variance of the digital regression coefficient is biggest out of 7 companies. In other words, the numerical value of the digital regression coefficient isn't stable. When the analog regression coefficient and the digital regression coefficient are compared, there are a lot of periods when the one of the digital coefficient is big (5 periods: Except for the single regression analysis period when analog will be NA). A tendency is not seen in the time series variation.

Table 2: The result of analysis (Canon)

\begin{tabular}{|c|c|c|c|c|c|c|c|c|c|}
\hline $\begin{array}{c}\text { Measurement } \\
\text { starting year }\end{array}$ & $\begin{array}{l}\text { Choice } \\
\text { model } \\
\text { AmDn }\end{array}$ & $\begin{array}{l}\text { Decision } \\
\text { coefficient }\end{array}$ & $\begin{array}{l}\text { Statistically } \\
\text { significant }\end{array}$ & VIF & $\begin{array}{c}\text { Regression } \\
\text { coefficient } \\
\text { (Analog } \\
\text { Pat.) }\end{array}$ & $\begin{array}{c}\text { P Value } \\
\text { (Analog } \\
\text { Pat.) }\end{array}$ & $\begin{array}{c}\text { Regression } \\
\text { coefficient } \\
\text { (Digital } \\
\text { Pat.) }\end{array}$ & $\begin{array}{c}\text { P Value } \\
\text { (Digital } \\
\text { Pat.) }\end{array}$ & AIC \\
\hline 2001 & A2D2 & 0.95 & $* * *$ & 1.03 & -3.37 & $* * *$ & 5.23 & $* * *$ & 142.78 \\
\hline 2002 & A3D3 & 0.93 & $* * *$ & 1.03 & -3.27 & $* * *$ & 4.34 & $* * *$ & 142.77 \\
\hline 2003 & A0D2 & 0.92 & $* * *$ & 1.00 & 1.80 & $* *$ & 4.21 & $* * *$ & 138.84 \\
\hline 2004 & A3D3 & 0.87 & $* * *$ & 1.14 & -1.97 & $* *$ & 3.33 & $* * *$ & 136.93 \\
\hline 2005 & A1D6 & 0.81 & $* * *$ & 1.47 & -3.36 & $* * *$ & 2.10 & $* * *$ & 139.08 \\
\hline 2006 & AXD1 & 0.84 & $* * *$ & NA & NA & NA & -4.36 & $* * *$ & 139.41 \\
\hline 2007 & A3D0 & 0.93 & $* * *$ & 1.68 & -1.87 & $* *$ & -3.43 & $* * *$ & 138.17 \\
\hline Max. Value & & 0.95 & & 1.68 & 1.80 & & 5.23 & & 142.78 \\
\hline Min. Value & & 0.81 & & 1.00 & -3.37 & & -4.36 & & 136.93 \\
\hline Mean & & 0.89 & & 1.23 & -2.01 & & 1.63 & & 139.71 \\
\hline Valiance & & 0.00 & & 0.08 & 3.96 & & 15.26 & & 5.02 \\
\hline
\end{tabular}

* The $\mathrm{p}$ value is significant in $90 \%$ level.

** The $\mathrm{p}$ value is significant in $95 \%$ level.

*** The $\mathrm{p}$ value is significant in $99 \%$ level.

\subsection{Nikon}

After a starting period in 2002 , there are 0 years time lag between "application of an analog patent" and "the total shipment".

After a starting period in 2002 , there are 3 years time lag between "application of an digital patent" and "the total shipment". A time lag of digital patents is longer than a time lag of analog patents. The average of the digital regression coefficient is biggest out of 7 companies. The 
variance of the digital regression coefficient is smallest out of 7 companies. In other words, 1 application of a digital patent relates to the growth rate of the shipment quantity biggest out of 7 companies. Because variance is small, an annual change in the regression coefficient is small and stable. It shows that an association between quantity of the applications and shipment quantity of the digital patent is stable. In all between the seventh, a digital patent coefficient is bigger than an analog patent coefficient. On the other hand, the analog coefficient tends to be increased.

Table 3: The result of analysis (Nikon)

\begin{tabular}{cccccccccc}
\hline $\begin{array}{c}\text { Measurement } \\
\text { starting year }\end{array}$ & $\begin{array}{c}\text { Choice } \\
\text { model } \\
\text { AmDn }\end{array}$ & $\begin{array}{c}\text { Decision } \\
\text { coefficient }\end{array}$ & $\begin{array}{c}\text { Statistically } \\
\text { significant }\end{array}$ & $\begin{array}{c}\text { VIF } \\
\text { Regression } \\
\text { coefficient } \\
\text { (Analog } \\
\text { Pat.) }\end{array}$ & $\begin{array}{c}\text { P Value } \\
\text { (Analog } \\
\text { Pat.) }\end{array}$ & $\begin{array}{c}\text { Regression } \\
\text { coefficient } \\
\text { (Digital } \\
\text { Pat.) }\end{array}$ & $\begin{array}{c}\text { P Value } \\
\text { (Digital } \\
\text { Pat.) }\end{array}$ & AIC \\
\hline 2001 & A5D1 & 0.97 & $* * *$ & 1.03 & -0.75 & $* *$ & 3.63 & $* * *$ & 124.61 \\
2002 & A0D3 & 0.96 & $* * *$ & 1.34 & 1.46 & $* *$ & 4.22 & $* * *$ & 130.40 \\
2003 & A0D3 & 0.98 & $* * *$ & 1.14 & 1.04 & $*$ & 4.36 & $* * *$ & 127.17 \\
2004 & A0D3 & 0.98 & $* * *$ & 1.20 & 1.23 & $* *$ & 4.15 & $* * *$ & 122.70 \\
2005 & A0D3 & 0.97 & $* * *$ & 1.01 & 1.69 & $* * *$ & 4.04 & $* * *$ & 125.41 \\
2006 & A0D3 & 0.95 & $* * *$ & 1.01 & 2.15 & $* * *$ & 4.08 & $* * *$ & 130.04 \\
2007 & A0D3 & 0.92 & $* * *$ & 1.01 & 2.55 & $* * *$ & 4.03 & $* * *$ & 136.60 \\
\hline Max. Value & & 0.98 & & 1.34 & 2.55 & & 4.36 & & 136.60 \\
Min. Value & & 0.92 & & 1.01 & -0.75 & & 3.63 & & 122.70 \\
Mean & & 0.96 & & 1.11 & 1.34 & & 4.07 & 128.13 \\
Valiance & & 0.00 & & 0.02 & 1.12 & & 0.05 & & 21.80 \\
\hline
\end{tabular}

\subsection{Sony}

After a starting period in 2002 , there are 3 or 4 years time lag between "application of an analog patent" and "the total shipment". On the other hand, "the time lag between the application of the digital patent and the shipment" aren't stable. When the analog regression coefficient and the digital regression coefficient are compared, there are a lot of periods when the one of the analog coefficient is big (4 periods: Except for the single regression analysis period when digital will be NA). When it's compared with a digital patent, the relation between the analog patent and the shipment quantity is big.

Table 4: The result of analysis (Sony)

\begin{tabular}{|c|c|c|c|c|c|c|c|c|c|}
\hline $\begin{array}{l}\text { Measurement } \\
\text { starting year }\end{array}$ & $\begin{array}{l}\text { Choice } \\
\text { model } \\
\text { AmDn }\end{array}$ & $\begin{array}{c}\text { Decision } \\
\text { coefficient }\end{array}$ & $\begin{array}{l}\text { Statistically } \\
\text { significant }\end{array}$ & VIF & $\begin{array}{c}\text { Regression } \\
\text { coefficient } \\
\text { (Analog } \\
\text { Pat.) }\end{array}$ & $\begin{array}{c}\text { P Value } \\
\text { (Analog } \\
\text { Pat.) }\end{array}$ & $\begin{array}{c}\text { Regression } \\
\text { coefficient } \\
\text { (Digital } \\
\text { Pat.) }\end{array}$ & $\begin{array}{c}\text { P Value } \\
\text { (Digital } \\
\text { Pat.) }\end{array}$ & AIC \\
\hline 2001 & A1D6 & 0.88 & $* * *$ & 1.04 & 13.66 & $* * *$ & 5.07 & $* *$ & 146.27 \\
\hline 2002 & A3DX & 0.88 & $* * *$ & NA & 11.03 & $* * *$ & NA & NA & 141.49 \\
\hline 2003 & A4D3 & 0.95 & $* * *$ & 1.63 & 2.39 & $* *$ & 5.64 & $* * *$ & 130.57 \\
\hline 2004 & A3D0 & 0.94 & $* * *$ & 1.03 & 10.23 & $* * *$ & 1.70 & $* *$ & 129.91 \\
\hline 2005 & A3D6 & 0.96 & $* * *$ & 1.04 & 12.16 & $* * *$ & -1.75 & $* *$ & 128.82 \\
\hline 2006 & A3D6 & 0.97 & $* * *$ & 1.00 & 12.91 & $* * *$ & -1.59 & $* *$ & 129.18 \\
\hline 2007 & A3DX & 0.97 & $* * *$ & NA & 12.72 & $* * *$ & NA & NA & 131.68 \\
\hline Max. Value & & 0.97 & & 1.63 & 13.66 & & 5.64 & & 146.27 \\
\hline Min. Value & & 0.88 & & 1.00 & 2.39 & & -1.75 & & 128.82 \\
\hline Mean & & 0.94 & & 1.15 & 10.73 & & 1.81 & & 133.99 \\
\hline Valiance & & 0.00 & & 0.07 & 14.87 & & 12.39 & & 48.42 \\
\hline
\end{tabular}




\subsection{Panasonic}

When it's compared with a digital patent, the time lag between the application of an analog patent and the total shipment is big through an analysis period. The time lag of a digital patent is short ( 2 years in 3 periods of first half, 1 year in 4 periods of second half). When it's compared with a digital patent, the time lag of an analog patent is long. But the time lag of an analog patent is on the decline to the period second half. It becomes A3D1 or A2D1 in a period in the latter half and shows approximately constant value. The average of a digital patent coefficient is the second biggest in seven companies. In addition, the variance of a digital patent coefficient is the second smallest in seven companies. When it's compared with the digital coefficient, there are a lot of periods with the big analog coefficient (4 periods).

Table 5: The result of analysis (Panasonic)

\begin{tabular}{cccccccccc}
\hline $\begin{array}{c}\text { Measurement } \\
\text { starting year }\end{array}$ & $\begin{array}{c}\text { Choice } \\
\text { model } \\
\text { AmDn }\end{array}$ & $\begin{array}{c}\text { Decision } \\
\text { coefficient }\end{array}$ & $\begin{array}{c}\text { Statistically } \\
\text { significant }\end{array}$ & $\begin{array}{c}\text { VIF } \\
\text { Regression } \\
\text { coefficient } \\
\text { (Analog } \\
\text { Pat.) }\end{array}$ & $\begin{array}{c}\text { P Value } \\
\text { (Analog } \\
\text { Pat.) }\end{array}$ & $\begin{array}{c}\text { Regression } \\
\text { coefficient } \\
\text { (Digital } \\
\text { Pat.) }\end{array}$ & $\begin{array}{c}\text { P Value } \\
\text { (Digital } \\
\text { Pat.) }\end{array}$ & AIC \\
\hline 2001 & A6D2 & 0.98 & $* * *$ & 1.98 & 8.00 & $* * *$ & 3.04 & $* * *$ & 120.76 \\
2002 & A4D2 & 0.96 & $* * *$ & 1.58 & 4.41 & $* * *$ & 3.41 & $* * *$ & 123.40 \\
2003 & A4D2 & 0.87 & $* * *$ & 1.37 & 3.18 & $* *$ & 3.60 & $* * *$ & 133.24 \\
2004 & A3D1 & 0.86 & $* * *$ & 1.33 & 5.45 & $* * *$ & 4.59 & $* * *$ & 131.33 \\
2005 & A3D1 & 0.86 & $* * *$ & 1.57 & 5.17 & $* * *$ & 4.44 & $* * *$ & 131.17 \\
2006 & A2D1 & 0.90 & $* * *$ & 1.11 & 2.52 & $*$ & 3.30 & $* * *$ & 129.18 \\
2007 & A3D1 & 0.96 & $* * *$ & 1.00 & 1.65 & $*$ & 4.04 & $* * *$ & 122.51 \\
\hline Max. Value & & 0.98 & & 1.98 & 8.00 & & 4.59 & & 133.24 \\
Min. Value & & 0.86 & & 1.00 & 1.65 & & 3.04 & 120.76 \\
Mean & & 0.91 & & 1.42 & 4.34 & & 3.77 & & 127.37 \\
Valiance & & 0.00 & & 0.11 & 4.54 & & 0.35 & 25.17 \\
\hline
\end{tabular}

\subsection{Casio}

The average of AIC of Casio is lowest during 7 companies of this analysis. In other words, applying of a regression analysis result of Casio is best compared with other 6 companies. A time lag between the application of an analog patent and the shipment is 3 years in all 7 starting periods. A time lag between the application of a digital patent and the shipment is 1 year in all 7 starting periods. When it's compared with an analog patent, the time lag of a digital patent is short. When it's compared with the digital coefficient, the analog coefficient is big besides the last 1 period. When it's compared with 6 companies of other ones, the change amount of the analog coefficient is small. In other words, the relation between the analog patent application and the shipment quantity is stable. 
Table 6: The result of analysis (Casio)

\begin{tabular}{|c|c|c|c|c|c|c|c|c|c|}
\hline $\begin{array}{l}\text { Measurement } \\
\text { starting year }\end{array}$ & $\begin{array}{l}\text { Choice } \\
\text { model } \\
\text { AmDn }\end{array}$ & $\begin{array}{l}\text { Decision } \\
\text { coefficient }\end{array}$ & $\begin{array}{c}\text { Statistically } \\
\text { significant }\end{array}$ & VIF & $\begin{array}{c}\text { Regression } \\
\text { coefficient } \\
\text { (Analog } \\
\text { Pat.) }\end{array}$ & $\begin{array}{c}\text { P Value } \\
\text { (Analog } \\
\text { Pat.) }\end{array}$ & $\begin{array}{c}\text { Regression } \\
\text { coefficient } \\
\text { (Digital } \\
\text { Pat.) }\end{array}$ & $\begin{array}{c}\text { P Value } \\
\text { (Digital } \\
\text { Pat.) }\end{array}$ & $\mathrm{AIC}$ \\
\hline 2001 & A3D1 & 0.89 & $* * *$ & 1.23 & 4.44 & $* * *$ & 2.33 & $* * *$ & 119.62 \\
\hline 2002 & A3D1 & 0.92 & $* * *$ & 1.19 & 4.42 & $* * *$ & 1.99 & $* * *$ & 113.52 \\
\hline 2003 & A3D1 & 0.78 & $* * *$ & 1.04 & 4.06 & $* *$ & 2.55 & $* *$ & 122.77 \\
\hline 2004 & A3D1 & 0.95 & $* * *$ & 1.00 & 5.60 & $* * *$ & 4.31 & $* * *$ & 109.82 \\
\hline 2005 & $\mathrm{~A} 3 \mathrm{D} 1$ & 0.96 & $* * *$ & 1.02 & 5.37 & $* * *$ & 4.22 & $* * *$ & 109.72 \\
\hline 2006 & A3D1 & 0.94 & $* * *$ & 1.13 & 5.69 & $* * *$ & 4.38 & $* * *$ & 114.85 \\
\hline 2007 & A3D1 & 0.96 & $* * *$ & 1.56 & 5.11 & $* * *$ & 5.41 & $* * *$ & 112.47 \\
\hline Max. Value & & 0.96 & & 1.56 & 5.69 & & 5.41 & & 122.77 \\
\hline Min. Value & & 0.78 & & 1.00 & 4.06 & & 1.99 & & 109.72 \\
\hline Mean & & 0.91 & & 1.17 & 4.96 & & 3.60 & & 114.68 \\
\hline Valiance & & 0.00 & & 0.04 & 0.42 & & 1.68 & & 24.06 \\
\hline
\end{tabular}

\subsection{Fuji film}

After a starting period in 2004 , there are 5 or 6 years time lag between "application of patents (analog and digital each)" and "the total shipment". When it's compared with another company, the time lag of Fuji film is longest. An average of coefficient of an analog patent and of the digital patent is the lowest price out of 7 companies.

Table 7: The result of analysis (Fuji Film)

\begin{tabular}{|c|c|c|c|c|c|c|c|c|c|}
\hline $\begin{array}{l}\text { Measurement } \\
\text { starting year }\end{array}$ & $\begin{array}{l}\text { Choice } \\
\text { model } \\
\text { AmDn }\end{array}$ & $\begin{array}{l}\text { Decision } \\
\text { coefficient }\end{array}$ & $\begin{array}{c}\text { Statistically } \\
\text { significant }\end{array}$ & VIF & $\begin{array}{c}\text { Regression } \\
\text { coefficient } \\
\text { (Analog } \\
\text { Pat.) }\end{array}$ & $\begin{array}{c}\text { P Value } \\
\text { (Analog } \\
\text { Pat.) }\end{array}$ & $\begin{array}{c}\text { Regression } \\
\text { coefficient } \\
\text { (Digital } \\
\text { Pat.) }\end{array}$ & $\begin{array}{l}\text { P Value } \\
\text { (Digital } \\
\text { Pat.) }\end{array}$ & AIC \\
\hline 2001 & AXD5 & 0.86 & $* * *$ & NA & NA & NA & 1.09 & $* * *$ & 121.82 \\
\hline 2002 & A2D5 & 0.96 & $* * *$ & 1.02 & -0.65 & $* * *$ & 1.05 & $* * *$ & 110.84 \\
\hline 2003 & A5D0 & 0.90 & $* * *$ & 1.06 & 0.81 & $* * *$ & -0.71 & $* * *$ & 118.39 \\
\hline 2004 & A5D6 & 0.73 & $* * *$ & 1.00 & 1.29 & $* * *$ & 0.65 & $* *$ & 130.41 \\
\hline 2005 & A5D6 & 0.84 & $* * *$ & 1.00 & 1.57 & $* * *$ & 0.83 & $* *$ & 130.00 \\
\hline 2006 & A6D5 & 0.93 & $* * *$ & 1.63 & 1.04 & $* *$ & 1.39 & $* * *$ & 124.96 \\
\hline 2007 & A5D6 & 0.94 & $* * *$ & 1.28 & 1.47 & $* * *$ & 1.01 & $* * *$ & 126.97 \\
\hline Max. Value & & 0.96 & & 1.63 & 1.57 & & 1.39 & & 130.41 \\
\hline Min. Value & & 0.73 & & 1.00 & -0.65 & & -0.71 & & 110.84 \\
\hline Mean & & 0.88 & & 1.17 & 0.92 & & 0.76 & & 123.34 \\
\hline Valiance & & 0.01 & & 0.06 & 0.67 & & 0.47 & & 48.87 \\
\hline
\end{tabular}

\subsection{Olympus}

A time lag between the application of a patent (analog and digital each) and the shipment is less than 3 years. But it's the feature rarely to get the price continued in all 7 periods. When it's compared with the analog coefficient, the digital coefficient is often big. 
Table 8: The result of analysis (Olympus)

\begin{tabular}{cccccccccc}
\hline $\begin{array}{c}\text { Measurement } \\
\text { starting year }\end{array}$ & $\begin{array}{c}\text { Choice } \\
\text { model } \\
\text { AmDn }\end{array}$ & $\begin{array}{c}\text { Decision } \\
\text { coefficient }\end{array}$ & $\begin{array}{c}\text { Statistically } \\
\text { significant }\end{array}$ & $\begin{array}{c}\text { VIF } \\
\text { Regression } \\
\text { coefficient } \\
\text { (Analog } \\
\text { Pat.) }\end{array}$ & $\begin{array}{c}\text { P Value } \\
\text { (Analog } \\
\text { Pat.) }\end{array}$ & $\begin{array}{c}\text { Regression } \\
\text { coefficient } \\
\text { (Digital } \\
\text { Pat.) }\end{array}$ & $\begin{array}{c}\text { P Value } \\
\text { (Digital } \\
\text { Pat.) }\end{array}$ & AIC \\
\hline 2001 & A2DX & 0.82 & $* * *$ & NA & -2.05 & $* * *$ & NA & NA & 126.08 \\
2002 & A1D2 & 0.76 & $* * *$ & 1.40 & -2.59 & $* * *$ & -2.05 & $* *$ & 125.26 \\
2003 & A3D0 & 0.82 & $* * *$ & 1.91 & 1.66 & $* * *$ & 3.42 & $* * *$ & 118.74 \\
2004 & A3D0 & 0.92 & $* * *$ & 1.01 & 2.05 & $* * *$ & 3.63 & $* * *$ & 119.06 \\
2005 & A0D2 & 0.97 & $* * *$ & 1.02 & 6.25 & $* * *$ & 1.07 & $* *$ & 115.21 \\
2006 & A3D0 & 0.97 & $* * *$ & 1.43 & 3.14 & $* * *$ & 3.65 & $* * *$ & 117.69 \\
2007 & A0D2 & 0.97 & $* * *$ & 1.49 & 5.62 & $* * *$ & 1.03 & $*$ & 118.04 \\
\hline Max. Value & & 0.97 & & 1.91 & 6.25 & & 3.65 & & 126.08 \\
Min. Value & & 0.76 & & 1.01 & -2.59 & & -2.05 & 1.79 & 115.21 \\
Mean & & 0.89 & & 1.38 & 2.01 & & 1.05 & 120.01 \\
Valiance & & 0.01 & & 0.11 & 11.68 & & 5.07 & & 16.53 \\
\hline
\end{tabular}

\section{Consideration}

When a result of the time lag was analyzed, 7 companies were divided into "the manufacturer to which the tendency goes out clearly" and "the manufacturer by which the tendency isn't seen". The tendency of the time lag appeared in "both of analog and digital" by the analysis of Nikon, Panasonic, Fuji film and Casio. The tendency of the time lag appeared in analog by an analysis of SONY. The tendency of the time lag were not appeared by the analysis of Canon and Olympus. Description is added about "the manufacturer from which the tendency appeared". It's written in the first about the analysis of a time lag. Nikon which is an existence camera manufacturer is good at a system of the lens and analog technology of a shutter. When it's compared with an analog patent, the time lag of a digital patent of Nikon is long. When it's compared with analog technology with which Nikon is familiar, this shows that it takes time for digital technology to have an influence on shipment quantity. Panasonic and Casio which are new entry electronics manufacturers are good at image processing and technology of a picture device. When it's compared with an analog patent, the time lag of a digital patent of Panasonic and Casio are short. When it's compared with digital technology with which Panasonic and Casio are familiar, this shows that it takes time for analog technology to have an influence on shipment quantity. Next it's described about the analysis of the regression coefficient. In Nikon which is an existing camera maker, the value of the digital regression coefficient grows big than an analog regression coefficient in all between the seventh. When applying for 1 digital patent more than applying for 1 analog patent, shipment quantity of Nikon becomes big. In Panasonic and Casio which are new entry electronics manufacturers, the value of the digital regression coefficient grows small than an analog regression coefficient in all between the seventh. When applying for 1 digital patent more than applying for 1 analog patent, shipment quantity of Panasonic and Casio become small. The result of analysis of 3 companies, Nikon, Panasonic and Casio is integrated as follows. When it's compared with familiar technology, it takes time for non-familiar technology to have an influence on shipment quantity. When applying for 1 patent of familiar technology more than applying for 1 patent of non-familiar technology, shipment quantity become big. 


\section{Summary}

A digital camera is a strong product of Japanese export competitiveness. Quantitative analysis about "application patent data" and "digital camera shipment quantity" of 7 digital camera manufacturers was put into effect by this analysis. The application patent data which is an outcome of research and development was divided into analog technology and digital technology by quantitative analysis, and a time lag of an application patent and shipment quantity was considered. 63 kinds of time lag was considered in each analysis period covered in each company. The regression analysis was put into effect for 7 years (regression model of all 3087). When it's compared with familiar technology, it takes time for non-familiar technology to have an influence on shipment quantity. When applying for 1 patent of familiar technology more than applying for 1 patent of non-familiar technology, shipment quantity become big. It was 3 out of 7 companies that the tendency of the analysis appeared, its tendency was as follows. When it's compared with familiar technology, it takes time for non-familiar technology to have an influence on shipment quantity. When applying for 1 patent of familiar technology more than applying for 1 patent of non-familiar technology, shipment quantity become big. The manufacturer to which the tendency has not gone out can consider the following cause in this analysis. There is a possibility that change has occurred to research and development and a patent strategy during an analysis period. There is a possibility that market application of an outcome of research and development wasn't developed as scheduled. There is a possibility that a change has occurred to ambient surroundings. Source data of the quantity of applications of the digital camera related patent is being used by this analysis.

When an action after an application (reexamination request and registration circumstances) is seasoned, there is also a possibility that new knowledge is obtained. I'd like to try whether this analysis can also be applied in a fused product besides the digital camera field from now on.

\section{References}

[1] Comanor William S., and Frederic M. Scherer, "Patent statistics as a measure of technical change," Journal of political economy 77.3, 1969, pp. 392-398.

[2] Pavitt Keith, "R\&D, patenting and innovative activities: a statistical exploration," Research Policy 11.1, 1982, pp. 33-51.

[3] Kondo Masayuki, "R\&D dynamics of creating patents in the Japanese industry," Research Policy 28.6, 1999, pp. 587-600.

[4] Artz K. W., Norman P. M., Hatfield D. E., and Cardinal L. B., "A longitudinal study of the impact of $R \& D$, patents, and product innovation on firm performance," Journal of product innovation management 27.5, 2010, pp. 725-740.

[5] Lev Baruch, and Theodore Sougiannis, "The capitalization, amortization, and valuerelevance of R\&D," Journal of accounting and economics 21.1, 1996, pp. 107-138.

[6] Pakes Ariel, "Patents as options: Some estimates of the value of holding European patent stocks," ,1984. 
[7] Kodama Fumio, "Technological diversification of Japanese industry," Science 233.4761, 1986, pp. 291-296.

[8] Tsuji Youichirou S, "Organizational behavior in the R\&D process based on patent analysis: Strategic R\&D management in a Japanese electronics firm," Technovation 22.7, 2002, pp. 417-425.

[9] Suzuki Jun, and Fumio Kodama, "Technological diversity of persistent innovators in Japan: Two case studies of large Japanese firms," Research Policy 33.3, 2004, pp. 531-549.

[10] Bergek Anna, and Christian Berggren, "Technological internationalisation in the electrotechnical industry: a cross-company comparison of patenting patterns 19862000,"Research Policy 33.9, 2004, pp. 1285-1306.

[11] Pilkington Alan, and Romano Dyerson, "Innovation in disruptive regulatory environments: A patent study of electric vehicle technology development," European Journal of Innovation Management 9.1, 2006, pp. 79-91.

[12] Deng Zhen, Baruch Lev, and Francis Narin, "Science and technology as predictors of stock performance," Financial Analysts Journal 55.3, 1999, pp. 20-32.

[13] Cooper Robert G., and Elko J. Kleinschmidt, "New products: what separates winners from losers?,"Journal of product innovation management 4.3, 1987, pp. 169-184.

[14] Henard David H., and David M. Szymanski, "Why some new products are more successful than others," Journal of marketing Research 38.3, 2001, pp. 362-375.

[15] Song X. Michael, and Mark E. Parry, "A cross-national comparative study of new product development processes: Japan and the United States," Journal of marketing 61.2, 1997, pp. $1-18$.

[16] Chery Nakata, Subin Im, Heungsoo Park, and Young-Won Had, "Antecedents and consequence of Korean and Japanese new product advantage," Journal of Business Research 59.1, 2006, pp. 28-36.

[17] Pandit Shail, Charles E. Wasley, and Tzachi Zach, "The effect of research and development $(R \& D)$ inputs and outputs on the relation between the uncertainty of future operating performance and R\&D expenditures," Journal of Accounting, Auditing \& Finance 26.1, 2011, pp. 121-144.

[18] Chen Yu-Shan, and Ke-Chiun Chang, "Exploring the nonlinear effects of patent citations, patent share and relative patent position on market value in the US pharmaceutical industry," Technology Analysis \& Strategic Management 22.2, 2010, pp. 153-169.

[19] Katila Riitta, and Gautam Ahuja, "Something old, something new: A longitudinal study of search behavior and new product introduction," Academy of management journal 45.6, 2002, pp. 1183-1194.

[20] Conley James G., Peter M. Bican, and Holger Ernst, "Value articulation: a framework for 
the strategic management of intellectual property," California Management Review 55.4, 2013, pp. 102-120.

[21] Mitkova Liliana, "Marketing: a key element in patent management," International journal of technology transfer and commercialisation 4.4, 2005, pp. 487-499.

[22] Lieberman Marvin B., and David B. Montgomery, "First-mover advantages," Strategic management journal 9.S1, 1988, pp. 41-58.

[23] Teece David J, "Towards an economic theory of the multiproduct firm," Journal of Economic Behavior \& Organization 3.1, 1982, pp. 39-63.

[24] Bernard Andrew B., Stephen J. Redding, and Peter K. Schott, "Multiple-product firms and product switching," American Economic Review 100.1, 2010, pp. 70-97.

[25] Goto Mika, Angie Low, and Anil K. Makhija, "Diversification, Productivity, and Financial Constraints Empirical Evidence from the US Electric Utility Industry," Ohio State University, Charles A. Dice Center for Research in Financial Economics Working Paper Series 3, 2008.

[26] Bergek A., Berggren C., Magnusson T., and Hobday M., "Technological discontinuities and the challenge for incumbent firms: Destruction, disruption or creative accumulation?" Research Policy 42.6-7, 2013, pp. 1210-1224.

[27] Schnaars Steven P. Managing imitation strategies. Simon and Schuster, 2002.

[28] Pakes Ariel, and Zvi Griliches, "Patents and R\&D at the firm level: A first report," Economics letters 5.4, 1980, pp. 377-381.

[29] Griliches Zvi, "Market value, R\&D, and patents," R\&D, Patents, and Productivity. University of Chicago Press, 1984, pp. 249-252.

[30] Akaike Hirotogu, "Information theory and an extension of the maximum likelihood principle," Selected papers of hirotugu akaike. Springer, New York, NY, 1998, pp. 199-213. 


\section{Appendix}

Table 9: Description of Analog Patent (G02B1 G02B17)

\begin{tabular}{|c|c|}
\hline IPC & Descriptions \\
\hline$\cdot \mathrm{G}$ & PHYSICS \\
\hline - $\mathrm{G} 02$ & OPTICS \\
\hline - G02B & OPTICAL ELEMENTS, SYSTEMS, OR APPARATUS \\
\hline - G02B1/00 & $\begin{array}{l}\text { Optical elements characterised by the material of which they are made; } \\
\text { Optical coatings for optical elements }\end{array}$ \\
\hline - G02B3/00 & Simple or compound lenses \\
\hline - $\mathrm{G} 02 \mathrm{~B} 5 / 00$ & Optical elements other than lenses \\
\hline - $\mathrm{G} 02 \mathrm{~B} 6 / 00$ & Light guides \\
\hline - G02B7/00 & $\begin{array}{l}\text { Mountings, adjusting means, or light-tight connections, for optical } \\
\text { elements }\end{array}$ \\
\hline - G02B9/00 & $\begin{array}{l}\text { Optical objectives characterised both by the number of the components } \\
\text { and their arrangements according to their sign, i.e. }+ \text { or }-\end{array}$ \\
\hline - G02B11/00 & $\begin{array}{l}\text { Optical objectives characterised by the total number of simple and } \\
\text { compound lenses forming the objective and their arrangement }\end{array}$ \\
\hline - $\mathrm{G} 02 \mathrm{~B} 13 / 00$ & Optical objectives specially designed for the purposes specified below \\
\hline - G02B15/00 & Optical objectives with means for varying the magnification \\
\hline - G02B17/00 & Systems with reflecting surfaces, with or without refracting elements \\
\hline
\end{tabular}

Table 10: Description of Analog Patent (G03B1 G03B19)

\begin{tabular}{|c|c|}
\hline IPC & Descriptions \\
\hline$\cdot \mathrm{G}$ & PHYSICS \\
\hline \multirow[t]{2}{*}{$\cdot \mathrm{G} 03$} & CINEMATOGRAPHY; \\
\hline & $\begin{array}{l}\text { TECHNIQUES USING WAVES OTHER THAN OPTICAL WAVES; } \\
\text { ELECTROGRAPHY; HOLOGRAPHY }\end{array}$ \\
\hline \multirow[t]{5}{*}{$\cdot$ G03B } & APPARATUS OR ARRANGEMENTS \\
\hline & PHOTOGRAPHS OR FOR PROJECTING OR VIEWING THEM; \\
\hline & APPARATUS OR ARRANGEMENTS EMPLOYING ANALOGOUS \\
\hline & $\begin{array}{l}\text { TECHNIQUES USING WAVES OTHER THAN OPTICAL WAVES; } \\
\text { ACCESSORIES THEREFOR }\end{array}$ \\
\hline & ACCESSORIES THEREFOR \\
\hline • G03B1/00 & Film strip handling \\
\hline • G03B3/00 & $\begin{array}{l}\text { Focusing arrangements of general interest for cameras, projectors or } \\
\text { printers }\end{array}$ \\
\hline • G03B5/00 & $\begin{array}{l}\text { Adjustment of optical system relative to image or object surface other } \\
\text { than for focusing }\end{array}$ \\
\hline • G03B7/00 & $\begin{array}{l}\text { Control of exposure by setting shutters, diaphragms or filters, separately } \\
\text { or conjointly }\end{array}$ \\
\hline • G03B9/00 & Exposure-making shutters; Diaphragms \\
\hline - G03B11/00 & Filters or other obturators specially adapted for photographic purposes \\
\hline - G03B13/00 & $\begin{array}{l}\text { Viewfinders; Focusing aids for cameras; Means for focusing for } \\
\text { cameras; Autofocus systems for cameras }\end{array}$ \\
\hline - G03B15/00 & Special procedures for taking photographs; Apparatus therefor \\
\hline - G03B17/00 & Details of cameras or camera bodies; Accessories therefor \\
\hline - G03B19/00 & Cameras \\
\hline
\end{tabular}


Table 11: Description of Digital Patent (H04N5/22 25)

\begin{tabular}{ll}
\hline \multicolumn{1}{c}{ IPC } & \multicolumn{1}{c}{ Descriptions } \\
\hline$\cdot \mathrm{H}$ & ELECTRICITY \\
$\cdot \mathrm{H} 04$ & ELECTRIC COMMUNICATION TECHNIQUE \\
$\cdot$ H04N & PICTORIAL COMMUNICATION, e.g. TELEVISION \\
$\cdot$ H04N5/00 & Details of television systems \\
$\cdot$ H04N5/222 & Studio circuitry; Studio devices; Studio equipment \\
$\cdot$ H04N5/225 & Television cameras \\
$\cdot$ H04N5/228 & Circuit details for pick-up tubes \\
$\cdot$ H04N5/232 & Devices for controlling television cameras, e.g. remote control \\
$\cdot$ H04N5/235 & Circuitry \{or methods\} for compensating for variation in the brightness \\
& of the object \\
$\cdot$ b04N5/238 & by influencing the optical part of the camera \\
$\cdot$ H04N5/243 & by influencing the picture signal \\
$\cdot$ H04N5/247 & Arrangements of television cameras \\
$\cdot$ H04N5/253 & Picture signal generating by scanning motion picture films or slide \\
$\cdot$ H04N5/257 & opaques, e.g. for telecine \\
\hline
\end{tabular}


Table 12: Description of Digital Patent (H04N5/33 36, H01L27/146 148)

\begin{tabular}{|c|c|}
\hline IPC & Descriptions \\
\hline$\cdot \mathrm{H}$ & ELECTRICITY \\
\hline$\cdot \mathrm{H} 04$ & ELECTRIC COMMUNICATION TECHNIQUE \\
\hline$\cdot \mathrm{H} 04 \mathrm{~N}$ & PICTORIAL COMMUNICATION, e.g. TELEVISION \\
\hline$\cdot \mathrm{H} 04 \mathrm{~N} 5 / 00$ & Details of television systems \\
\hline - H04N5/33 & Transforming infra-red radiation \\
\hline$\cdot \mathrm{H} 04 \mathrm{~N} 5 / 335$ & using solid-state image sensors \\
\hline$\cdot \mathrm{H} 04 \mathrm{~N} 5 / 341$ & $\begin{array}{l}\text { Extracting pixel data from an image sensor by controlling scanning } \\
\text { circuits, e.g. by modifying the number of pixels having been sampled } \\
\text { or to be sampled }\end{array}$ \\
\hline$\cdot$ H04N5/343 & $\begin{array}{l}\text { by switching between different modes of operation using different } \\
\text { resolutions or aspect ratios, e.g. between still and video mode or } \\
\text { between interlaced and non-interlaced mode }\end{array}$ \\
\hline$\cdot \mathrm{H} 04 \mathrm{~N} 5 / 345$ & by partially reading an SSIS array \\
\hline$\cdot \mathrm{H} 04 \mathrm{~N} 5 / 347$ & by combining or binning pixels in SSIS \\
\hline$\cdot \mathrm{H} 04 \mathrm{~N} 5 / 349$ & for increasing resolution by shifting the sensor relative to the scene \\
\hline$\cdot \mathrm{H} 04 \mathrm{~N} 5 / 351$ & $\begin{array}{l}\text { Control of the SSIS depending on the scene, e.g. brightness or motion } \\
\text { in the scene }\end{array}$ \\
\hline$\cdot \mathrm{H} 04 \mathrm{~N} 5 / 353$ & Control of the integration time \\
\hline$\cdot \mathrm{H} 04 \mathrm{~N} 5 / 355$ & Control of the dynamic range \\
\hline$\cdot \mathrm{H} 04 \mathrm{~N} 5 / 357$ & $\begin{array}{l}\text { Noise processing, e.g. detecting, correcting, reducing or removing } \\
\text { noise }\end{array}$ \\
\hline$\cdot \mathrm{H} 04 \mathrm{~N} 5 / 359$ & $\begin{array}{l}\text { applied to excess charges produced by the exposure, e.g. smear, } \\
\text { blooming, ghost image, crosstalk or leakage between pixels }\end{array}$ \\
\hline$\cdot \mathrm{H} 04 \mathrm{~N} 5 / 361$ & applied to dark current \\
\hline$\cdot \mathrm{H} 04 \mathrm{~N} 5 / 363$ & applied to reset noise, e.g. KTC noise \\
\hline$\cdot \mathrm{H} 04 \mathrm{~N} 5 / 365$ & applied to fixed-pattern noise, e.g. non-uniformity of response \\
\hline$\cdot \mathrm{H} 04 \mathrm{~N} 5 / 367$ & applied to defects, e.g. non-responsive pixels \\
\hline$\cdot \mathrm{H} 04 \mathrm{~N} 5 / 369$ & SSIS architecture; Circuitry associated therewith \\
\hline$\cdot \mathrm{H}$ & ELECTRICITY \\
\hline$\cdot \mathrm{H} 01$ & BASIC ELECTRIC ELEMENTS \\
\hline - H01L & 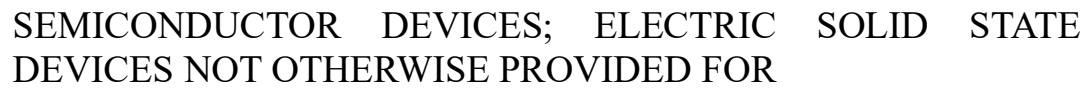 \\
\hline - H01L27/00 & $\begin{array}{l}\text { Devices consisting of a plurality of semiconductor or other solid-state } \\
\text { components formed in or on a common substrate }\end{array}$ \\
\hline • H01L27/146 & Imager structures \\
\hline - H01L27/148 & Charge coupled imagers \\
\hline
\end{tabular}

